\title{
The Relationship between Empirical Legal Studies and Doctrinal Legal Research
}

\author{
Gareth Davies*
}

\section{Abstract}

This article considers how empirical legal studies (ELS) and doctrinal legal research (DLR) interact. Rather than seeing them as competitors that are methodologically independent and static, it suggests that they are interdependent activities, which may each be changed by interaction with the other, and that this change brings both opportunities and threats. For ELS, the article argues that DLR should properly be understood as part of its theoretical framework, yet in practice little attention is given to doctrine in empirical work. Paying more attention to DLR and legal frames generally would help ELS meet the common criticism that it is undertheorised and excessively policy oriented. On the other hand, an embrace of legal thinking, particularly of critical legal thinking, might lead to loss of status for ELS in policy circles and mainstream social science. For DLR, ELS offers a chance for it to escape the threat of insular sterility and irrelevance and to participate in a founded commentary on the world. The risk, however, is that in tailoring legal analysis to what can be empirically researched legal scholars become less analytically ambitious and more safe, and their traditionally important role as a source of socially relevant critique is weakened. Inevitably, in offering different ways of moving to normative conclusions about the law, ELS and DLR pose challenges to each other, and meeting those challenges will require sometimes uncomfortable self-reflection.

Keywords: empirical legal studies, legal research methods, doctrinal legal research, new legal realism, critical legal studies, law and policy

\section{Introduction}

There has been a trend for some years for American law schools to expand the amount of empirical research done within their walls, and this trend is spreading to Europe. ${ }^{1}$ As with any new entry into a competitive field - and research is certainly competitive on the individual, institutional and perhaps national levels - this development raises the questions: who wins and who loses?

Gareth Davies is Professor of European Law at the Faculty of Law of the Vrije Universiteit Amsterdam

1. J. Balkin, 'Interdisciplinarity as Colonization', 53 Washington and Lee Law Review 949 (1996); E. Chambliss, ‘When Do Facts Persuade Some Thoughts on the Market for Empirical Legal Studies', 71 Law and Contemporary Problems 17 (2008); R. van Gestel and H. Micklitz, 'Methods in European Legal Scholarship', 20 European Law Journal 292 (2014).
The most obvious and immediate axes of competition are between empirical legal studies (ELS) and traditional doctrinal legal research (DLR) and between law faculties and faculties of social science. The expansion of ELS could be seen as a move by assertive social scientists to challenge DLR as a way of speaking about law in society or as a move by assertive (and, in the US, rich) law schools to challenge faculties of social science at their own game.

That is not to say that the process is necessarily a simple head-to-head contest. Absorption, interdisciplinarity or failed colonisation as Balkin thought-provokingly calls it - and fragmentation are among the reactions that disciplines may provoke when they meet. ${ }^{2}$ As ELS expands, it may find that the environment of the law school changes it - that it absorbs more qualitative methods and is more and more subject to the theoretical frames found in legal thinking rather than those drawn purely from social and human sciences. If law schools successfully become major players in the (largely quantitative) social science world, they may find that doing so changes their own character and diminishes their autonomy, as they become subject to the methodological disciplines of a wider field. The coloniser is, inevitably, also changed, even to some extent colonised. ${ }^{3}$

I am interested in how the future of ELS and doctrine, and law schools, will reveal itself, and whether a simple competition for dominance will play out or whether, in particular, ELS and doctrine will exert mutual influence and perhaps converge in method and interests and what that will mean for all those involved.

One small step towards forming an expectation about this - a predictive theory perhaps - is to think about the principled relationship between ELS and DLR. What is it that they each try to do? What are their essential differences? In what ways are they related, even interdependent? This does not tell us how their futures will develop, but it hints at how they might and may contribute to thinking about how they should. It provides a basis, perhaps, for future empirical research.

This article tries to explore that relationship. It begins, inevitably, with a brief account of the rise of ELS, which it tries to place in the context of other legal research movements, as well as institutional and educational developments. It then moves on to ask how the relationship, or interrelationship between ELS and DLR, is often idealised and how it has been in practice 
and, finally, which relationship would be the most coherent and synergetic. Then, in the last part of the article, the price of that coherent synergy is explored. If ELS and DLR become part of a shared project to understand the working of law in action, they each, inevitably, give up some autonomy, both in their research agendas and their methodology. How do they change and what do they give up if they come within the orbit of each other?

To some extent this debate has been had. There is extensive scholarly work on the methodological and political problems of ELS - from a lawyer's, particularly a critical lawyer's, perspective - as well as robust defences of it. Much of this will be rehearsed in the text that follows. However, my aim in looking at this critique is not to see which kind of research is 'best', however that might be defined. Instead, the critique will be used to help understand how different ways of studying the legal system could influence each other and what there is to be gained and lost by the existing methodological communities. In particular, I want to explore this from a European perspective, which is why I place DLR central, the archetypal law school activity, rather than the more critical-theoretical or overtly political forms of legal commentary that tend to dominate debate in the US. $^{4}$

Having said that, in what follows, I take DLR to be a relatively broad church. It does not encompass pure legal theory, nor Critical Legal Studies (CLS) in its most radical form, that is to say where any positivist understanding of the law at all is treated as irrelevant. ${ }^{5}$ However, it does include scholarship that seeks to theorise on the basis of law, as well as the traditional exposition of law. It is all that legal scholarship that begins with, or rests upon, some form of positivist investigation, as I perceive most European legal scholarship does, wherever that investigation may ultimately lead. ${ }^{6}$ What the law 'is' may be a question that many scholars recognise to be complex, indeterminate, unanswerable, often misleading, and perhaps even dangerous, but it continues to inform their agendas for research. How will it change if law schools move to invest in the empirical measurement of what the law 'does'?

\section{The Emergence of Empirical Legal Studies}

\subsection{The Space that ELS Fills}

Empirical research into the origins, working and consequence of law has a reasonably long history, with Legal Realism often being named as the movement that first

4. Van Gestel and Micklitz, above n. 1; E.V. Towfigh, 'Empirical Arguments in Public Law Doctrine: Should Empirical Legal Studies Make a "Doctrinal Turn"?' 12 ICON 670 (2014).

5. G. Shaffer, 'The New Legal Realist Approach to International Law', 28 Leiden Journal of International Law 189 (2015).

6. J. Vranken, 'Exciting Times for Legal Scholarship', 2(2) Law and Method 42 (2012) gave it a prominent place in the legal academy. ${ }^{7}$ The legal realists' assertion that there was a difference between 'law in the books' and 'law in action', as it is sometimes phrased today, ${ }^{8}$ was a challenge to the adequacy of doctrine as a way of explaining or understanding law. Legal Realism has in turn been traced back to the 'Free Law' movement in early 20th century Germany. ${ }^{9}$

Once scholars accepted that law could be studied in non-doctrinal ways, this opened the door to a rich variety of perspectives and methods, from feminist, postcolonial and critical legal studies to law and economics, passing through sociolegal studies, sociological jurisprudence and McDougall-Lasswell policy science, to mention a few of the schools within broader legal studies. ${ }^{10}$ The areas of academic life, and indeed the countries, where these managed to gain a foothold and achieve prominence have varied, as do their political and methodological agendas.

Many of these approaches were developed by lawyers, or within law schools, or have at least found a comfortable niche within the legal academy and coexist in a more or less stable, if not quite symbiotic, relationship with more doctrinal approaches. Indeed, law schools are the traditional homes of interdisciplinary research - one is far more likely to find a philosopher, psychologist or political scientist within a law school than vice versa. However, the approaches to studying legal processes that rely on the most orthodox social science methods, and which are the most traditionally empirical and quantitative, have tended to be centred within faculties of social science or economics, where the necessary methodological expertise lies. ${ }^{11}$ Until recently, this research, and the work of more traditional doctrinal lawyers, has existed largely in a state of comfortable mutual indifference - mutual citation, for example, being exceptional and mostly symbolic. ELS is often understood as an attempt to change this - to bring mainstream social science methods into law schools and to legitimate the empirical approach to law among lawyers. ${ }^{12}$ This is

7. Van Gestel and Micklitz, above n. 1.

8. P. Mascini and W. van Rossum, 'Empirical Legal Research: Fad, Feud or Fellowship?', 11(2) Erasmus Law Review 89 (2018).

9. J. Herget and S. Wallace, 'The German Free Law Movement as the Source of American Legal Realism', 73 Virginia Law Review 399 (1987).

10. See for overviews e.g. R. Unger, 'The Critical Legal Studies Movement', 96 Harvard Law Review 561 (1983); E. Christodoulidis, R. Dukes \& M. Goldoni (eds.), Research Handbook on Critical Legal Theory (2019); N. Kreutzfeldt, M. Mason \& K McConnachie, Routledge Handbook of Socio-Legal Theory and Methods (2019); R. Cotterell, Sociological Jurisprudence: Juristic Thought and Social Enquiry (2017); R. Posner, 'The Law and Economics Movement', 77(2) The American Economic Review 1 (1987). P. Zumbansen, 'Transnational Law as Socio-Legal Theory: The Challenges for "Law in Context" in a Divided World', 67 Buffalo Law Review 909 (2019); J. Van Doren and C. J. Roedererer, 'McDougal-Lasswell Policy Science: Death and Transfiguration', 11 Richmond Journal of Global Law and Business 125 (2012).

11. J. Baldwin and G. Davis, 'Empirical Research in Law', in M. Tushnet and P. Cane (eds.), The Oxford Handbook of Legal Studies (2005) 880.

12. Ibid.; T.J. Miles and C.R. Sunstein, 'The New Legal Realism', 75 University of Chicago Law Review 831 (2008); M.C. Suchman and E. Mertz, 'Toward a New Legal Empiricism: Empirical Legal Studies and 
proving to be disruptive, both institutionally and intellectually.

ELS, and the trend it represents, did not emerge from nowhere. It can be seen as the product, perhaps culmination, of a number of empirical legal movements of recent years, beginning with the 'law and' movement, of the second half of the twentieth century. ${ }^{13}$ The most prominent part of this was law and economics in the US, which, in typically economic style, offered not just an apparently empirically and theoretically founded description of law but also a normative guide to its use: a complete ideology of law. While profoundly influential in the US, it did not have the same impact in Europe and has tended to be relatively self-contained: believers and non-believers have relatively little to say to each other. The other important 'law and' was the Law and Society movement (LS), which tries to understand the interaction between rules and their social context and was the heir to legal realism and the forerunner of ELS. ${ }^{14}$

The most well-known mission statement of ELS, to do 'legally sophisticated empirical [analysis]' is not inherently different or conflicting with that of $\mathrm{LS},{ }^{15}$ or the movement known as New Legal Realism (NLR), which emerged around the same time as ELS, just before the millennium. ${ }^{16}$ It has been commented that these three groups are porous and overlapping in terms of both the people participating and the subjects and methods. ${ }^{17}$ However, there are widespread perceptions of differences in style, politics and methodology, particularly between LS and ELS. NLR is somewhat less prominent, and considered closer to LS in spirit, and is more driven by legal academics. ${ }^{18}$

ELS is generally considered to have a largely quantitative methodological orientation, and to be primarily policy oriented, although in ELS journals and conferences this is usually not formalised - it is merely present as a prevailing orientation. ${ }^{19}$ The contrast is with LS, which is typically more qualitative, self-reflective, methodologically diverse and critical. ${ }^{20}$ Lawyers who identify with the LS movement often have a progressive social

New Legal Realism', 6 Annual Review of Law and Sociology 555 (2010); D. Blocq and M. van der Woude, 'Making Sense of the Law and Society Movement', 11(2) Erasmus Law Review 134 (2018).

13. Generally, see T. Eisenberg, 'The Origins, Nature, and Promise of Empirical Legal Studies and a Response to Concerns', 5 University of Illinois Law Review 1713 (2011); Chambliss, above n. 1.

14. See Blocq and van der Woude, above n. 12.

15. T. Eisenberg, 'Why do Empirical Legal Scholarship?', 41 San Diego Law Review 1741, at 1741 (2004)

16. E. Mertz, S. Macaulay \& T. W. Mitchell (eds.), The New Regal Realism: Translating Law-and-Society for Today's Legal Practice (2016); H. Klug and S. E. Merry (eds.), The New Regal Realism: Studying Law Globally (2016)

17. Chambliss, above n. 1

18. Ibid.; Shaffer, above n. 5; M. McCann, 'Preface to the New Legal Realism', in Mertz, Macaulay \& Mitchell, above n. 16, xiii.

19. Towfigh, above n. 4; M. Suchman, ‘Empirical Legal Studies: Sociology of Law or Something ELS Entirely?' 13 AMICI 1 (2006); Chambliss, above n. 1; F. Bell, 'Empirical Research in Law', 25(2) Griffith Law Review 262 (2016).

20. Suchman, ibid.; Suchman and Mertz, above n. 12; Chambliss, above n. 1. agenda and desire to challenge assumptions and underlying values in the law. ${ }^{21} \mathrm{ELS}$ is often seen as providing practical advice to policymakers on the effectiveness of the law. It is further from doctrine and interpretation than LS, but closer to mainstream social sciences in method, and its tendency to avoid overt normativity. ${ }^{22}$ The empirical turn in legal studies is often said to be born partly out of a frustration with the limits of doctrine and with formalism. ${ }^{23}$ This is true in the US, and will be equally true in Europe, particularly in fields such as EU law, which are goal oriented and where lawyers need to move beyond textual interpretation if they wish their voice to be heard in policy debate. ${ }^{24}$ The specific contribution of ELS is to offer the kind of hard-nosed and digestible prescriptions that LS is less concerned with. Where frustration with doctrine concerns its lack of contextual awareness, reflectivity or self-critical capacity, LS is the more obvious response. Where that frustration concerns its inability to guide action, ELS fills a gap. Generational change and the emergence of younger scholars with interdisciplinary $\mathrm{PhDs}$ fuel both responses. ${ }^{25}$ What was once a way for a young lawyer to distinguish themselves - some knowledge of social science methods or at least ideas - has become so orthodox that it shapes the mainstream.

There are also more institutional considerations relevant to the emergence of ELS. It is located primarily in law schools considered to be among the elite in the US, and there are a number of reasons for this. ${ }^{26}$ One is that they have the funds to pay for relatively labour-intensive and therefore expensive empirical research. ELS does not mandate a new kind of research but rather brings together and consolidates empirical research relevant to law that previously took place primarily in faculties of social science, usually under a more traditional label, such as political science, criminology, sociology or social psychology. ${ }^{27}$ That research continues in those faculties but now faces competition from the ELS movement within law schools - a competitive challenge that only well-funded elite law schools would be able to make.

For those law schools, what they have to gain is threefold: academic status, educational advantage and policy influence. DLR is not a science, except perhaps in the most abstract hermeneutic sense, but rather an adjunct to a professional activity. ${ }^{28}$ While law schools enjoy wealth, good connections to power and a certain social status, within the academy their output is often regarded as irrelevant to other branches of knowledge. ELS allows them to speak a language accepted elsewhere in

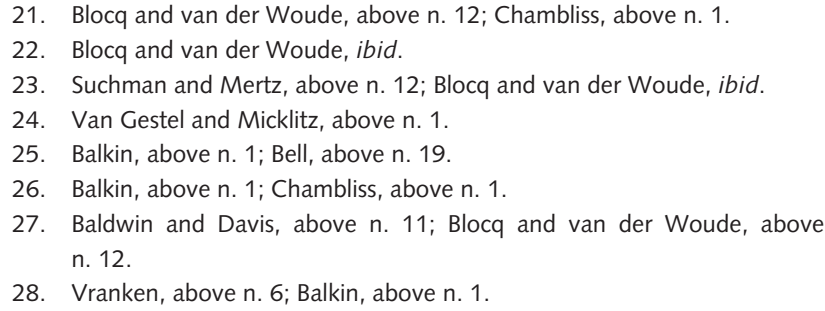


the academic world and broadens their sphere of influence. $^{29}$

ELS may also have an educational appeal. In the US, teaching is the major source of research funds, and attracting the right students is central to academic success. Offering an element of ELS in the curriculum allows elite law schools to distinguish themselves and to display the argument that the modern lawyer must be able to understand and use empirical data. ${ }^{30}$ Data-driven lawsuits and legal practice are particularly found in corporate and commercial practice, where elite law schools often have their centre of gravity. In the US, the appeal of ELS to law students may lie in the idea that it gives them a competitive edge. In Europe, it may be more relevant that it opens up traditionally dry and dogmatic legal education and offers the promise of an engagement with the issues of the day: that it makes a law degree less dull. Because continental law degrees are often seen as a general preparation for governmental or business work, rather than specifically for practice, law schools compete to some extent with economics and politics faculties and with the new breed of liberal-artsstyle degrees that are emerging in Europe. Rather than the aspirant student being forced to choose between learning about the world or learning about legal texts, a law curriculum with ELS offers the chance of doing both. ${ }^{31}$

However, the most important motive for investing in ELS is probably the chance to extend policy influence. ${ }^{32}$

Lawyers are well represented in networks of power, and law schools and law professors usually have little difficulty being heard in the policy world. However, they often have difficulty being listened to: where their contribution is confined to a normatively enhanced interpretative display it is not unusual for them to find themselves applauded, or attacked and then ignored. Policymakers typically seek data and evidence with which to back up their preferences - 'the minister wants a number' - and ELS allows legal institutions to supply this, along with the legal skills to translate that evidence into law. In a rhetorical reversal of the ELS mission, they can supply empirically sophisticated legal prescriptions.

\subsection{The Critique of ELS}

Doctrinal academic lawyers have often welcomed ELS as a potential source of data to strengthen their normative arguments. Even more often, they simply exist alongside it - in law schools where ELS flourishes there are typically many professors who nevertheless do traditional DLR. Active criticism of the movement has come primarily from what might be seen as the methodological extremes: those with a mainstream social sci-

29. A. Lang, 'New Legal Realism, Empiricism, and Scientism: The Relative Objectivity of Law and Social Science', 28 Leiden Journal of International Law 231 (2015); A. Bradney, 'Law as a Parasitic Discipline', 25 Journal of Law and Society 71 (1998).

30. A. Bradney, 'The Place of Empirical Legal Research in the Law School Curriculum', in P. Cane and H.M. Kritzer (eds.), The Oxford Handbook of Empirical Legal Research (2010) 1025.

31. Bradney (1998), above n. 29.

32. Towfigh, above n. 4. ence background or those who identify with the Critical Legal Studies (CLS) movement and its epistemological claims.

The simplest critique, made by a number of social scientists, is that what goes under the name of ELS is typically of low quality, meaning that it is methodologically weak. ${ }^{33}$ The implication was that lawyers were moving into a field they did not understand and making a mess of it. This claim caused quite an uproar and was fiercely contested. ${ }^{34}$ However, it is both a limited criticism and one that raises deeper questions.

It is limited in that it concerned only ELS that was published in legal journals. Not only is this research more likely to have been done by lawyers - who were not originally trained in empirical methods but presumably 'picked them up' somewhere - but it will also be less likely to have faced review by peers with the relevant method background, especially where American student-run law journals are concerned. ${ }^{35}$ This raises questions about how to make an interdisciplinary research community work, and those questions certainly need to be considered by law journal editors and legal researchers engaging in empiricism, but they are not ones that cannot be answered.

On the other hand, there is a deeper question raised about the ownership of method. The concern was about 'quality', but that is always defined with reference to a particular peer community, and the relevant question here is, which community is, or should be, the relevant one? Wherever a disciplinary community imports a method from another, one may expect the resulting research to take on a new character, not necessarily meeting the norms of its original users. ${ }^{36}$ Whether one wants to see this in terms of development, cross-fertilisation (or, wonderfully, 'cross-sterilisation' ${ }^{37}$ ) mutual learning, corruption, misunderstanding or misuse is context- and perspective specific. However, transplants are never merely additive, always transformative. The more ELS succeeds in not just penetrating legal institutions, but also converting their members, the more it may find itself becoming alienated from its source: many a missionary has gone native, becoming, in the

33. L. Epstein and G. King, 'The Rules of Inference', 69 University of Chicago Law Review 114 (2002); M.J. Madison, 'The Idea of the Law Review: Scholarship, Prestige and Open Access', 10 Lewis and Clark Law Review 901 (2006); G.N. Rosenberg, 'Across the Great Divide (Between Laws Political Science)', 3 Green Bag 267 (2000); M.L. Dauber, 'The Big Muddy', 57 Stanford Law Review 1899 (2005); F.B. Cross, 'Political Science and the New Legal Realism: A Case of Unfortunate Interdisciplinary Ignorance', 92 Northwestern University Law Review 251 (1997).

34. Eisenberg (2011), above n. 13; F. Cross et al., 'Above the Rules: A Response to Epstein and King', 69 University of Chicago Law Review 135 (2002); R.L. Revesz, 'A Defense of Empirical Legal Scholarship', 69 University of Chicago Law Review 169 (2002); J. Goldsmith and A. Vermeule, 'Empirical Methodology and Legal Scholarship', 69 University of Chicago Law Review 153 (2002). See also discussion in Chambliss, above n. 1

35. Chambliss, above n. 1

36. S. Macaulay, 'A New Legal Realism: Elegant Models and the Messy Law in Action', in Mertz, Macaulay \& Mitchell above n. 16, 29.

37. F.H. Easterbrook, 'Cyberspace and the Law of the Horse', University of Chicago Legal Forum 207, at 207 (1996). 
eyes of their church, too pagan. Social scientists may not like the ELS in law journals, but perhaps lawyers do.

By contrast, where ELS is published in traditional social science journals, of administration, governance, political science or criminology, it is more likely to have been done by people originally of that community, and to be methodologically orthodox. The quality critique was not made of this research. Rather, the question to be asked of this research is, what makes it ELS, rather than simply being political science or criminology, etc? Is the label purely a feature of institutional location, or is there plausibly a substantive defining feature of ELS as a discipline of its own? If so, that feature must have to do with its relationship to law rather than merely legal processes and power. As will be discussed, any such defining feature appears to be primarily aspirational rather than actual. ${ }^{38}$

The more profound critique of ELS is that 'the pull of the policy audience' has turned it into a venue for superficial, simplistic and under-theorised work, ${ }^{39}$ seeking to produce convenient and bite-sized bits of policy advice but abandoning pretensions to fundamental thinking about either law or social science. ${ }^{40} \mathrm{ELS}$, it is widely perceived, tends to concentrate on readily quantifiable low-level issues of the legal process, where it is straightforward to find a variable that is both relevant to policy and measurable, and thus to generate results that can easily be translated into recommendations. ${ }^{41}$ Has a change in labour law led to more permanent contracts? Has a change in tenancy law reduced the number of conflicts over a certain issue? Do individuals feel more accepting of the outcome of a lawsuit if the judge speaks in lay language or highly technical terms? And so on.

This kind of work is essentially applied research. It does not seek to add to or challenge prevailing theories regarding systems, processes or human behaviour but rather to give those theories practical application. It may be thought that in a situation of limited resources an ambitious university would want to shy away from work like this, which finds its natural home in governmentsponsored research and policy institutes, but will not lead to grand new theories, paradigm shifts or to mass citations in the most prestigious journals: it is not the stuff of which great universities are made. ${ }^{42}$ It may be more attractive to second-rank universities that do not think themselves capable of generating the most worldchanging research, but, in providing more modest, yet useful, results, see a niche where they may be rendered safe thanks to their usefulness, a sustainable business model. For top US law schools, it should be noted that they often also employ distinguished philosophical and social theorists. ELS is not their only finger in the nonlegal pie. For more modestly funded, and traditionally

38. See part 3.2 below.

39. A. Sarat and S. Silbey, 'The Pull of the Policy Audience', 10 Law \& Policy 97 (1988).

40. Miles and Sunstein, above n. 12; van Gestel and Micklitz, above n. 1; Baldwin and Davis, above n. 11; Suchman and Mertz, above n. 12.

41. Baldwin and Davis, above n. 11; Suchman, above n. 19.

42. Baldwin and Davis, ibid. more dogmatic, European law faculties, precisely the limited ambitions of ELS may make it an accessible way of gaining a first foothold outside of DLR.

The applied and applicable nature of ELS research brings other problems too. It invites oversimplification and decontextualisation. ${ }^{43}$ Practical advice needs causality, not just correlation, providing a temptation to insulate the subject of research from the complexities of reality through convenient assumptions and premises. Just as some economists adopted oversimplified views of human behaviour because that was necessary to enable them to produce workable and predictive theory, ${ }^{44}$ the temptation within ELS is not to think too deeply about the factors that may complicate a research result. If individuals are pleased when a judge addresses them in understandable lay language, may we conclude that this is a desirable addition to the legal process? Or should we go on to ask other questions - does that satisfaction feed populist egoism? How do judges feel about this requirement? How will the judiciary change if the job is more communicative, less technical - will that politicise it? Will giving in to the demand that litigants be addressed on their own terms lead to assertiveness within the legal system, a customer-is-king entitlement mentality that has other consequences? What is the social role of intimidation and hierarchy within legal processes and indeed society? ELS traditionally does not follow a reflective or reflexive path: it quits when it is ahead, when it has a usable result, rather than going on to see how that result could in turn be undermined or turned around. At its most blunt, the critique might be that ELS seeks to measure, not to understand, although it must be emphasised that this is not inherent in the nature of ELS as a movement or practice but merely a common perception of how it has tended to be performed to date. ${ }^{45}$ It may, in time, come to be seen as an unfair criticism, or one that was a symptom of youth.

A more fundamental development of this criticism comes from CLS scholars, who challenge the very foundation of positivistic social science. ${ }^{46}$ The idea that the world can be studied 'objectively' and that the object of this study can be distinguished from the person studying it, is rejected, in favour of the view that the objects of study, being social phenomena, are themselves constructed, in all their relational complexity, by the act of studying them. ${ }^{47}$ This, in the views of CLS scholars, gives a different task to the scholar, one of creating new consciousness, not revealing new facts. Trubek puts it beautifully (summarising the views, not endorsing them as his own):

43. Van Gestel and Micklitz, above n. 1; Suchman and Mertz, above n. 12.

44. A.K. Sen, 'Rational Fools: A Critique of the Behavioral Foundations of Economic Theory', 6 Philosophy \& Public Affairs 317 (1977); R. Thaler, Misbehaving: The Making of Behavioral Economics (2015).

45. D.M. Trubek and J. Esser, 'Critical Empiricism in American Legal Studies: Paradox, Program, or Pandora's Box', 14 Law \& Social Inquiry 3 (1989).

46. See also A. Argyrou, 'Making the Case for Case Studies in Empirical Legal Research', 13 Utrecht Law Review 95 (2017).

47. For discussion see Bell, above n. 19. 
The real problem is that the behaviorists' methods accept the world as it seems to be, both to the observer and the observed. For the Critical scholar, this world is a dream, and the task of scholarship is not simply to understand the dream, but to awaken the dreamers. $^{48}$

In the American scholarship there has been a long-running call for a 'critical empiricism' and also a disappointment that this has not arisen and that ELS continues to follow the path of 'scientism'. 49

Many ELS scholars will reject these criticisms in principle as showing a misunderstanding of what ELS is: it does not aim to promote a world view but to deliver relevant results. There may be an acceptance among ELS researchers that these results are indeed uncertain, limited and the result of a degree of simplification, and even that they are an act of social construction, but all these things are the price of helping to guide experimental and evidence-based policy - the jewel in the ELS crown. ${ }^{50}$ Policymakers have more use for concrete data, even if imperfect or incomplete, than for a nuanced new theory that embraces complexity and inconclusiveness. ${ }^{51}$ This leads to the final critique of ELS: that in practice it is not used to support evidence-based policymaking but is instead employed in a 'symbolic' way, to provide convenient support and a veneer of technocracy to predetermined normative positions. ${ }^{52}$ The minister who wants to tax less or punish more goes looking for a report that backs her up and no doubt supports funding for the next project from the research group that provides it.

This somewhat depressing picture of ELS in action rather than ELS in the books - may well be unfair. Those who do ELS will, it may be expected, tend to reject most of the foregoing criticisms, but precisely because they are primarily empirical researchers they will tend not to write articles theorising or critically analysing the role and nature of ELS: those who do, and those who write about what doing is, are different, if overlapping, communities. Those, on the other hand, who do write such articles will tend to be drawn from the ranks of more theoretically inclined social scientists outside the law school, or non-empirical lawyers - precisely those threatened by ELS. Regarding the latter, one may comment that when a new and empirical discipline arises within a textually oriented and argumentative community it must expect robustly critical, pene-

48. D.M. Trubek, 'Where the Action Is: Critical Legal Studies and Empiricism', 36 Stanford Law Review 575, at 618 (1984).

49. Trubek and Esser, above n. 45; S.S. Silbey and A. Sarat, 'Critical Traditions in Law and Society Research', 21 Law and Society Review 165 (1987).

50. C.L. Boyd, 'In Defense of Empirical Legal Studies', 63 Buffalo Law Review 363 (2015).

51. Sarat and Silby, above n. 39, at 123.

52. R. van Gestel and P. van Lochem, 'Evidence-Based Regulation and the Translation from Empirical Data to Normative Choices: A Proportionality Test', 2(2) Erasmus Law Review 120 (2018); Sarat and Silbey, above n. 39 , at 103-104; Baldwin and Davis, above n. 11. trating, defensive and often under-empiricised reactions: that is what lawyers do; that is why ELS exists.

At any rate, the critique of the quality of ELS publications was itself attacked for methodological weakness, ${ }^{53}$ and the perception of ELS as under-theoretical is put forward by authors drawing on their experience rather than being the conclusion of research that would meet ELS's own methodological demands. ${ }^{54}$ The CLS challenge to social science is intriguing but often amounts to less than it seems when applied to a concrete case: when data is impressive, most readers (not all ${ }^{55}$ ) will forgive a degree of unreflective positivism.

Nevertheless, sometimes it is enough to sow doubt. While the claim that DLR itself is tragically limited in what it can say about the world is beyond any doubt, it is clear that merely bringing empiricists into law schools and faculties does not necessarily result in fully rounded legal research. Whether or not they are factually true, the criticisms of ELS are coherent and suggest that there is a need to think about what kind of empirical research is both enhanced by being in a law faculty rather than being in its more natural methodological home, a faculty of social science - and in turn enhances the other research which that faculty hosts. That question can be read broadly, for law schools often host philosophers, and legal theorists and other types of nonlawyer or quasi-lawyer too. However, here I wish to turn to the more specific question of how ELS and DLR can, do and should interrelate.

\section{The Interdependence of Doctrinal and Empirical Legal Research}

\subsection{An Idealised Relationship}

One can mentally frame ELS and DLR as parallel activities or intersecting ones. ${ }^{56}$ Do they, in fact, ask the same questions? There is no single answer to this, as each question can be seen as part of another one, so the choice of how we place ELS and DLR in relation to each other is a product of our choice of frame and, in particular, the level of abstraction at which we think. Each frame adds something to our understanding. At one level, they pursue different paths. The traditional doctrinal lawyer is initially concerned with the question 'what is the law?' and on the basis of an answer to that may go on to consider whether the law is coherent and which values it expresses. Most doctrinal lawyers then indulge themselves in a normative comment on

53. See works cited above n. 33

54. Although see Baldwin and Davis, above n. 11

55. M. Fineman, 'Dominant Discourse, Professional Language, and Legal Change in Child Custody Decisionmaking', 101 Harvard Law Review 727 (1988).

56. Or overlapping: See J.M. Smits, 'Redefining Normative Legal Science: Towards an Argumentative Discipline', in F. Coomans, F. Grünfeld \& M. Kamminga (eds.), Methods of Human Rights Research (2009) 45. 
their findings and will often suggest likely consequences of the law in practice.

By contrast, ELS asks where law and the practices of legal systems come from - which actors and institutions and social factors cause laws and practices to come into being - and what effects they have. It is concerned with how individuals and institutions and society respond to and are affected by laws, as well as how those laws are used by different actors. What is done with the law, and what does the law lead to, in the actual world?

On another level of abstraction, one can see both of these activities as part of a common endeavour to decide what the law should be. Even if the individual researcher is not motivated by this - and many social scientists may be more interested in understanding social and psychological processes, whereas many doctrinal lawyers may be more interested in linguistic argument - most will accept that at least some of the value of their research is in helping those who make the law take good decisions. Such people might be legislators, or judges who interpret. In either case, both doctrinal and empirical arguments could be relevant to their decision-making. The lawyer will show how to make texts coherent and the meanings that words can plausibly bear and the normative symbolism that they carry. The social scientist will show which practical consequences a rule or ruling will have.

Certainly, neither of these tell us what we ought to do as such: many scientists will insist that the empirical and normative are non-overlapping categories. However, they are both necessary information for the person who does take normative decisions - they help provide a basis for deciding. Whether or not that is their goal, the lawyer and social scientist both make a distinct contribution to answering a complex and multisided question: what to do?

This second frame hints at how ELS and DLR can also be seen as interrelated and even interdependent. ${ }^{57}$ For the lawyer, empirical research is necessary for them to achieve their normative ambitions. ${ }^{58}$ They may show that the text of the law permits, for example, the exclusion of a particular interest, or the rewarding of a particular kind of behaviour, and then, as lawyers do, may abhor or celebrate this. However, rules exist alongside other rules, and are embedded in social structures and norms, so that their actual effects cannot be conclusively known merely from studying them in isolation. A contract law that takes no account of the relative bargaining power of the parties or a labour law that protects the rights of long-term employees or a corporate law that insists on the primacy of shareholder returns might, on the basis of purely doctrinal analysis, be argued to send certain normative messages that may or may not be wel-

57. H. Dagan, R. Kreitner \& T. Kricheli-Katz, 'Legal Theory for Legal Empiricists', 43(2) Law \& Social Inquiry 292 (2018); T. Kricheli-Katz and Y. Feldman, 'The Human Mind and Human Rights: A Call for an Integrative Study of the Mechanisms Generating Employment Discrimination across Different Social Categories', 9(1) The Law and Ethics of Human Rights 43 (2015).

58. Dagan, Kreitner \& Kritcheli-Katz, ibid come. However, their actual effects in the world cannot be fully known by reasoning alone, and while important aspects of those effects might seem, at first glance, obvious, it is a truism that complex systems sometimes lead to unexpected results. Whether and to what extent weaker parties benefit from paternalistic contract law or employees benefit from labour rights or society is harmed by profit primacy are empirical questions. Perhaps simple law aids weaker parties more than protective law or employment protection leads to demoralising work environments or amoral corporate law leads to progressive voluntary social movements, whereas progressive corporate law crowds out responsibility and compassion. Who really knows, without investigation of these things? To be taken seriously as commentary on the world - rather than just as an aid to practitioners legal scholarship needs empirics. ${ }^{59}$ Dagan, Kreitner and Kritcheli-Katz note that even Kelsen said that law should be effective - and thereby put empirics at the heart of law's legitimacy. ${ }^{60}$

The dependence in the other direction is less obvious, but there to be found. For inasmuch as ELS studies how the law comes into being, and which effects it has, it matters what the law actually is. ${ }^{61}$ That may in some cases be evident to any lay person who reads the text, but it is the non-lawyer's traditional mistake to think that legality is obvious. In many situations knowing what is actually prohibited and what is allowed is a complex matter that is the subject of the doctrinal lawyer's expertise. Procedure, for example, may interact with substance so that an apparent prohibition can be dissolved away by procedural or evidential games. Higher norms or principles may constrain lower ones, so that apparently strict rules turn out to be flexible or contingent. Doctrinal research, it may be said, reveals the structures of incentives in the law, in their full complexity, with their gaps and nuances and the way that these may be used. Without this knowledge, the empiricist has no idea whether what they are measuring has anything to do with the law, and so, as an honest empiricist, they do not know what to measure. ${ }^{62}$

An idealised relationship between DLR and ELS thus seems to be one of theory and observation, not unlike that which might be found in other sciences. ${ }^{63}$ The lawyer reveals the incentives in the law and suggests likely consequences. The social scientist brings additional psychological and social theory to provide a more developed model of consequences: and then tests it. ${ }^{64}$ Without the

59. P. Schlag, 'Spam Jurisprudence, Air Law, and the Rank Anxiety of Nothing Happening (a Report on the State of the Art)', 97 Georgetown Law Journal 803 (2009); Shaffer, above n. 5; Lang, above n. 29; van Gestel and Micklitz, above n. 1

60. Dagan, Kreitner \& Kritcheli-Katz, above n. 57, at 300.

61. And indeed what is meant by 'is': this article does not address the many varieties of positivism.

62. M. Siems, 'The Taxonomy of Interdisciplinary Legal Research: Finding the Way Out of the Desert', 7 Journal of Commonwealth Law and Legal Education 5 (2009); Towfigh, above n. 4; van Gestel and Micklitz, above n. 1.

63. Dagan, Kreitner \& Kritcheli-Katz, above n. 57

64. Kricheli-Katz and Feldman, above n. 57 
doctrine, the empirical research is incompletely theorised. Without the empirical research, the lawyer is condemned to speculation (as is the legal philosopher: see Galligan $^{65}$ ). DLR and ELS are two techniques that can make only persuasive statements about the world if they work together. ${ }^{66}$ Bringing ELS to law faculties then seems logical.

\subsection{The Relationship in Practice}

The foregoing does not appear to be a good description of how ELS and DLR interrelate in practice. Rather than interdependence they move in relative indifference to and ignorance of each other. ${ }^{67} \mathrm{ELS}$ is, in fact, most focused on aspects of the legal system that do not require detailed engagement with doctrine, such as criminology, victimology and more institutional issues such as the working of courts and the behaviour of judges. ${ }^{68}$ Even where empirical research is done on substantive legal questions, it tends to focus on easily measurable variables, such as case outcomes or language patterns in judicial decisions. ${ }^{69}$

Certainly, there are exceptions to this. There is a growing body of scholarship that genuinely tries to integrate the legal and empirical in its explanations of legal processes, and to theorise their relationship. ${ }^{70}$ In particular, there has been attention to the role of legal theory as a part of the frame for empirical research. ${ }^{71}$ However, the involvement of legal theory inevitably gives the research a complex conceptual basis and does not facilitate the delivery of punchy answers to immediate policy questions. This work tends to be less quantitative and more qualitative than mainstream ELS and more focused on empirical validation and investigation of legal-theoretical concepts than on serving policy as it is understood by policymakers. On the one hand, it offers the possibility of an enormously rich and novel approach to thinking about law, while still taking the content of the law seriously. ${ }^{72}$ On the other, it takes a different path and offers different functionality to the mass of ELS research. For these reasons, it is not the kind of research that is being pushed within law schools as part of the ELS wave. In implicit recognition of this distance from the practice-oriented search for measurability, those doing it tend to self-identify under the NLR flag, rather

65. D.J. Galligan, 'Legal Theory and Empirical Research', in P. Cane and H.M. Kritzer (eds.), The Oxford Handbook of Empirical Legal Research (2010) 976.

66. Towfigh, above n. 4; van Gestel and Micklitz, above n. 1.

67. Towfigh, above n. 4; E.H. Tiller and F. B. Cross, 'What Is Legal Doctrine', 100 Northwestern University Law Review 517 (2006); G. van Dijck, S. Sverdlov \& G. Buck, 'Empirical Legal Research in Europe: Prevalence, Obstacles, and Interventions', 2(2) Erasmus Law Review 105 (2018).

68. M. Partington, 'Empirical Legal Research and Policy-making', in P. Cane and H.M. Kritzer (eds.), The Oxford Handbook of Empirical Legal Research (2010) 1002; Miles and Sunstein, above n. 12; Baldwin and Davis, above n. 11

69. Tiller and Cross, above n. 67

70. See the special edition of Law and Social Inquiry on this: SYMPOSIUM: New Legal Realism's Second Decade: Toward a Theoretical Foundation for Legal Empiricism, 43(2) Law and Social Inquiry 292-584 (2018).

71. Dagan, Kreitner \& Kritcheli-Katz, above n. 57.

72. McCann, above n. 18, xiii. than ELS. ${ }^{73}$ Thus, while the DLR-ELS relationship is receiving attention, that attention is largely outside the DLR-ELS axis itself. Those who self-identify, and are perceived as falling within the ELS movement, largely manage to avoid engaging with the complexity of law, or legal thinking. ${ }^{74}$

That researchers trained in quantitative methods focus on the measurable is hardly strange: if you have a hammer, the world looks like a nail. Yet in avoiding research questions that require engagement with the nuance and complexity of doctrine, empirical researchers raise the question whether what they are doing is not merely criminology, sociology or political science. Why the ELS label? Where is the legal sophistication that was promised? That may, of course, not matter to them ELS is primarily something that law schools and faculties like to proclaim an interest in, rather than an identity for researchers. However, it invites us to consider whether the use of the ELS brand is not, above all, a political move: an attempt to claim branches of social and human sciences for the legal academy - rather as economists have tried to claim aspects of psychology for themselves by calling those aspects 'behavioural economics'. Whether this is the case, and if so why, would be a worthy study in itself - but not one that I can pursue further here.

This article is more concerned with the consequences for research, and for understanding, that this distance between ELS and DLR brings. One risk is that where empirical research focuses on concrete variables such as outcomes or word patterns, it risks missing the importance of judicial decisions, since this often lies less in the immediate outcome of the case and more in the doctrine that is laid down, whose consequences may appear over years, and in other fields. ${ }^{75}$ Interpretation, the lawyer's art, helps see how statements of law may grow, change and exert influence within the wider legal field. Reducing cases to their non-doctrinal aspects, or reading laws without doctrinal context, gives a static and potentially misleading picture of what laws and judges are actually doing. ${ }^{76}$

Indeed, it has been commented that ELS tends to see laws as propositions to be tested: a law represents a policy intention, and the question is whether it has been achieved. ${ }^{77}$ One difficulty with this instrumental understanding is that the aims within law are often far more complex and even contradictory than is first apparent. A law is a political compromise whose symbolic, disruptive, second-order and indirect effects may be as essential to its nature as its apparent direct purpose.

73. Mertz, Macaulay \& Mitchell, above n. 16; H. Dagan and R. Kreitner, 'The New Legal Realism and the Realist View of Law', 43(2) Law and Social Inquiry 528 (2018).

74. Tiller and Cross, above n. 67

75. T.M. Hagle, 'Two Worlds, Neither Perfect: A Comment on the Tension between Legal and Empirical Studies', 63 Buffalo Law Review 379 (2015); Tiller and Cross, ibid.

76. Tiller and Cross, ibid.

77. Suchman and Mertz, above n. 12, at 560. 
In 'testing' laws, empirically, researchers engage in what has been called, by LS scholars primarily, 'gap studies': what is the gap between law in the books and law in action? ${ }^{78}$ The risk of oversimplification of the law, discussed in the preceding paragraphs, is a symptom of a more structural problem with this way of thinking about law: it problematises the gap as such, as if the 'wish' of law should 'be' the reality of behaviour. ${ }^{79}$ There is an implicit naïve positivism. ${ }^{80}$

Yet law is not a description of the world. Even as an ideal this is problematic - the capacity to disobey, and a diversity of responses to rules, are part of the humanity that law aims to protect. It is certainly inadequate as a theoretical paradigm for studying how law actually works. Rather, law needs to be understood in a much broader sense, as an intervention, an expression and a tool, which may be used in different ways in different circumstances and which may restructure incentives and cause actors to behave differently, and perhaps even reform ways of thinking and being. An excessive focus on 'the gap' will lead researchers to ignore the many other aspects of law and the complexity and diversity of its effects, and this in turn may tempt them into simplistic prescriptions, assessing the desirability of a law purely on its first-order consequences, as if the possibilities created, the messages sent, the ideas inspired and the interactions with other rules were mere side effects, when sometimes they are what matter most, and mostly they matter enough to be taken into account. ${ }^{81}$

\subsection{The Potential Gains and Losses}

The question remains: who wins and who loses? A simple utopian story is as follows: bringing ELS to law schools means that law schools will produce more relevant and useful research, which is more scientific in character. ${ }^{82}$ Their status - and potential funding ${ }^{83}$ - will be enhanced within the academy. Instead of merely serving law firms, they will serve society. They will also become more attractive to students as they become able to fulfil the youthful need to engage not just with rules but with social issues. Law teachers - doctrinal lawyers - will see their work become important outside their immediate circle, as it becomes the basis of empirical research and testing that can lead to new policy and law. They will be part of a socially important scientific process, not just an adjunct to practice, and not just participants in an insular legal-theoretical conversation. Empirical legal scholars, the social scientists within law schools, will find that as their work becomes legally more sophisticated, and more relevant to specific and actual laws, it is more appealing and useful to legal and policy actors and is likely to have more impact.

78. Baldwin and Davis, above n. 11; Blocq and van der Woude, above n. 12.

79. Blocq and van der Woude, above n. 12

80. Chambliss, above n. 1.

81. Blocq and van der Woude, above n. 12

82. Van Gestel and Micklitz, above n. 1.

83. Bell, above n. 19 .
The downsides, the losers, are to be found in the silences in the foregoing story. Firstly, there is likely to be pressure to produce 'testable' doctrinal research. DLR may become simpler and more transparent, more modular and digestible. The kind of legal scholarship that deploys untested and untestable social and political 'theories' and nevertheless reaches normative conclusions may be marginalised. For some that may be a welcome growing up for legal scholarship, as lawyers learn not to claim too much and to be more Popperian and modest. Yet legal scholarship has traditionally had more of a political function than a scientific one: it develops ideas about law and power that even if not proven, or provable, resonate in public debate and cause change. If law is to become part of science, this rhetorical, inspirational and speculative function risks being subordinated to the slower and more incremental search for measurable 'truth'. ${ }^{84}$

The question, perhaps, is what use we have for theory that cannot be realistically tested. Some would say 'none' - and if publication in empirically oriented journals is our standard, then that answer will be correct. Yet an alternative answer is that empirics is slow, difficult and unreliable, particularly in the social sciences. To reach sophisticated and definitive conclusions on how laws work often takes too long - politics sometimes has to act now. Fortunately, there are other forms of knowledge about society - the lived experience that is the basis of political views, or the common sense that lawyers and judges have traditionally used. Claims can, in the political and the personal spheres, and indeed in the legal, be judged in other ways than by social science methods. Almost all individuals, including empirical social scientists, take normative standpoints on issues where they are not familiar with the empirical evidence or where that evidence is absent or incomplete. Legal scholarship helps this, by providing arguments and analysis.

An alternative response to the challenges of measurement is to use qualitative methods. ELS is largely associated with the quantitative. For the lawyer whose normative claims are too grandiose or complex (essentially, politically, indeterminable) for easy quantitative testing, the qualitative may offer relief. To reduce a critical legal perspective, or a postcolonial or postmodern one, to quantifiable and measurable variables may be a challenge - although no doubt some will embrace it, sometimes. To develop it empirically via qualitative measures may be more welcome - to use interviews, stories, first-person perspectives, anthropological immersion and observation, and so on. There is a natural synergy between the low-n (less quantitatively oriented) social scientist and the theoretically minded legal scholar. ${ }^{85}$ One begins with words and the other with people, but each is more interested in sketching the contours of a vision of society that they grasp, intermittently and

84. Van Gestel and Micklitz, above n. 1.

85. Argyrou, above n. 46; Lang, above n. 29; Shaffer, above n. 5; McCann, above n. 18. 
incompletely, than in describing that vision in quantitative terms. They are content to extrapolate from the personal.

The risk for traditional ELS is that in law schools it is put under pressure to become more methodologically embracing and to accept empirical methods more sympathetic to what lawyers want to do. Qualitative methods may allow lawyers to reach out more effectively to colleagues in the humanities and some social scientists, and even to the public, but they may undermine the status of ELS in the worlds where it currently moves, the methodologically strict quantitative branches of social science. This is particularly so if the research is selfconsciously 'critical', aiming to reveal false consciousness rather than facts. ${ }^{86}$ The label of ELS may become unattractive to those doing quantitative science, who may prefer to be identified by their training as sociologists, psychologists or even economists. ELS may become a flag abandoned by its first carriers and then borne aloft by a new tribe. In legal scholarship 'one cannot take the meaning of empirical for granted' ${ }^{87}$

\section{Conclusion}

Both DLR and ELS are searching for their place in the academic world. Doctrinal lawyers are frustrated with the limits of their knowledge and skills and seek to engage with empirics in order to broaden their descriptive and normative scope. They do not necessarily want to do empirical research - most lawyers writing about empirical research do not actually do $\mathrm{it}^{88}-$ but they want to draw on it, and they want it to be research that meets their needs and their questions. ${ }^{89}$

ELS is still primarily conventional social science and has not yet shown what it is that defines it as a discipline - Suchman describes it as an ' $\mathrm{I}$ ' in search of a 'me'. ${ }^{90}$ The obvious answer, legal sophistication, part of its original raison d'etre, has not yet been realised to any great extent. Without that, it offers little sustenance to lawyers and has little identity of its own.

Understanding of the law could be greatly enhanced if empirical and doctrinal methods could be brought together - if research questions could be jointly formulated and results jointly assessed. This is surely the intention of investment by law schools in ELS. But at the same time, the two should not rush into each other's arms uncritically.

For empiricists, the risk is methodological corruption. If they embrace interdisciplinarity too enthusiastically, they may lose status and standing in the methodologically strict wider social science world and become one of the bubbles in which academia abounds: self-citing communities that through some accident of financing enjoy institutional stability and strong internal coherence but have limited external influence. It would not be a happy end.

For lawyers, the risk is watering down of their primary role as makers of arguments - or developers of ideas if one prefers. Legal interpretation is not a science, but a skill that provides influential and valuable conceptual input into academia, politics and society. If legal scholarship were to become safe, as scholars focused their interpretation on matters suitable for empirical research, the societal loss would be enormous. It would be as if natural scientists decided to abandon the development of theory in order to apply what they already had: a short-term rush of useful results would mask longerterm stagnation of ideas. It may be, of course, that in a time of polarisation, where universities and governments are quite often at odds, this is precisely what (some) government funders want. 